\title{
Biodegradation of Tannic Acid, Chromium and Cadmium Present in Leather Industrial Effluents Using Microorganisms Isolated from Leather Industrial Sludge
}

\author{
Roselin K. ${ }^{1}$, J. Caroline Rose ${ }^{2}$ \\ ${ }^{1}$ Asst. Professor and HoD, Department of Biochemistry, Sri Bhagawan Mahaveer Jain First Grade College, \\ K.G.F. \\ ${ }^{2}$ Asst. Professor, Department of Biotechnology, Arignar Anna Arts and Science College, Krishnagiri.
}

\section{ABSTRACT}

The present work was aimed to isolate indigenous predominant adapted Bacterial strains from tannery waste which possess the ability to detoxify and degrade Tannic acid, Chromium and Cadmium from tannery effluent. Fifteen bacterial strains were isolated from tannery sludge samples out of which Paracoccus pantotrophus (Tannery Waste 15) and Bacillus velezensis (Tannery Waste 17) were found to be the most efficient isolates. Degradation of Tannic acid, Cadmium and Chromium were evaluated for the two selected isolates. Better degradation of heavy metals was recorded in co-cultured media on day 7. From the study, it is evident that both $P$. pantotrophus and $B$. velezensis have has the ability to degrade tannic acid with maximum degradation on day 7 and absorbance was found to be 0.915 and 0.383 respectively. The strain $P$. pantotrophus showed better tannic acid degradation than $B$. velezensis. Better degradation was observed with coculturing of both the strains with absorbance of 0.274. Optimal cadmium degradation was observed on day 7 with OD 2.013 and 1.709 for $B$. velezensis and $P$. pantotrophus respectively. $P$. pantotrophus showed better cadmium degradation when compared to $B$. velezensis. Chromium degradation was maximum on day 7 and absorbance was 2.096 for P. pantotrophus and 0.560 for $B$. velezensis. The isolates recorded an acceptable reduction in the concentration of Tannin, Chromium and Cadmium in tannery effluent. The results of this
\end{abstract}

showed that the isolates reduced the concentration of Tannin, Chromium and Cadmium present in the raw tannery effluent and suggest that the organisms can be used as a possible treatment of tannery effluents.

Key Words: Bio-degradation, Bacillus velezensis, Paracoccus pantotrophus, Chromium, Cadmium, Tannic acid, Tannery effluent.

\section{INTRODUCTION}

Water is a vital natural resource for all living forms. Water is being polluted by fast growth of population, metropolitanization and mechanization (Singanan et al. 2007). Industrialization causes various environmental problems like water, land and air pollution. The wastewater originated from industries which are released into channels either untreated or inadequately treated causing water pollution. Industrial effluents such as tannery effluent contains a high amount of by-products, solid wastes, rich in organic wastes, different load of pollutants and emissions into the air. The polluted effluents are released onto the land as well as into the surface water, ground water and lead to contamination due to accumulation of toxic metallic components. This result into a series of problems when consumed, because 
they are partially or cannot be completely degraded (Malarkodi et al., 2007).

The use of chromium in various products and application in various industrial processes has emitted considerable environmental contamination (Sultan and Hasnain 2007). Tanning industries broadly uses chromium compounds to convert animal skins and hides into leather, mainly Chromium Sulphate. Generally, tanneries produce waste water in range of $30-35 \mathrm{~L} / \mathrm{kg}$ with total Chromium $23.3-42.5 \mathrm{mg} / \mathrm{L}$. Other industries such as metal finishing, petroleum refining, iron and steel production, inorganic chemicals production, textile manufacturing and pulp-producing industries also contributed in chromium contamination. Chromium is liberated into the environment via deprived storage, leakage or improper treatment and disposal practices. In India, more than $50 \%$ of the total chromium effluent discharge originates from the leather, iron and steel industries (Garg et al. 2012, 2015). In recent studies it has been cleared that $\mathrm{Cr}$ is responsible for asthma, wheezing, coughing and other respiratory problems (Langard, 1980)

The pattern of toxicity and accumulation of heavy metals in the atmosphere is a significant danger to the health of living organisms (Ayangbenro and Babalola 2017). Heavy metal exposure has been one of the global concerns due to its high toxicity, high bioaccumulation in the human body and food chain, the essence of non-biodegradability and most likely human carcinogenicity (He and Chen 2014). Among various heavy metals ions, the stable chromium species (Cr (III) and $\mathrm{Cr}$ (VI)) are known to be toxic to aquatic and terrestrial life. The hexavalent form is reportedly highly toxic and carcinogenic. The toxicity effects of chromium depend on its oxidation states. Accordingly, hexavalent chromium $\mathrm{Cr}$ (VI) is more harmful, cancerous, teratogenic, mutagenic and movable than trivalent chromium.

Cadmium contamination also reported particularly in soils containing waste materials from zinc mines and in sludge amended soils with cadmium rich phosphate fertilizers (Raskin and Ensley, 2000). The existing low market price of cadmium motivates the development of new applications may develop into new sources of emissions to the environment not covered by existing guideline Hence, the decontamination of these pollutants through bioremediation process and other biotechnological means are prerequisite for any future decision by the governments. The probable use of metal-resistant microorganisms in the treatment of heavy metal contaminated wastewater plants has become more important (Shakibaie et al., 2008). Various biomass types, such as bacteria, fungi and algae, have been screened and studied extensively by many authors over the decades with the aim of identifying highly efficient metal removal biological systems (Viraraghavan, 1995; Vieira and Volesky, 2000; Kapoor and Herrero et al., 2005).

Tannins are toxic, high molecular weight polyphenols that according to their structure are classified into hydrolysable and condensed ones (Frutos et.al. 2004, Dai and Mumper2010). Tannins are one of the most abundant plant components after cellulose, hemicellulose and lignin (.Mueller-Harvey 2001).

Toxicity of tannery effluent is due to the presence of high concentrations of tannins. Tannins are of plant origins and are used for tanning of skin and hide. Unused tannins present in the effluent have toxic effects on the protoplasm of living cells of animals, plants and microorganisms (Sivasamy(1982), Viswarajan(19881). Tannins adversely affect not only the yield of crops but also are detrimental to the useful microorganisms such as Azotobacter and Rhizobium (Lewis JA, Starkey RL (1968), Mark I, Stanley D (1981).

In recent years, there is a growing interest in the potential use of microorganisms for tannin degradation. Degradation of tannic acid and tannins by fungi and yeast has been well documented 
(Chandra (1973)). But, fungi are slow degraders and cause atmospheric pollution through their spores. Bacteria are considered highly sensitive to tannins but some isolates survive and even degrade tannins (Deschamps, 1980). Chemical methods are often available for elimination of chromium in majority from industrial effluent but they often fail to meet the environmental regulations. In chemical treatment very harmful chemicals are discharged which are toxic as well as harmful to environment. So microbial treatment of CTLS may be better alternative in comparison with chemical treatment for this purpose as the chemical agents add to the environmental pollution. Microbial treatment involves all kinds of microbes like bacteria, fungus, etc. Study has conveyed potential of some species of bacteria like Pseudomonas, Bacillus and Arthrobacter for reducing the level of chromium (Megharaj, (2003), Piñón-Castillo, H., et al., (2010)).

So, the present study aims to investigate the ability of natural inhabitant bacteria of tannery effluent in reducing and detoxifying of heavy metals $\mathrm{Cr}$ and $\mathrm{Cd}$ and organic molecule Tannin at privileged conditions, where objectives include isolation of naturally occurring bacteria from tannery sludge, screening of top two isolates as the reducer of Cr. Cd and Tannin, characterization of heavy metal and tannin resistance, identification of those bacteria up to genus as a fundamental research to ensure the basis of their resistance in order to use them for detoxification in an incorporated biodegradation scheme.

\section{MATERIALS AND METHOD Sample collection}

The tannery raw effluent samples were collected from the Leather Processing Industry Site in Vellore District, Tamil Nadu, in sterile different containers and were transported to the research Laboratory ,Bangalore for microbiological and biodegradation analysis.

\section{Preparation of bacterial culture in effluent sample}

Prepared $200 \mathrm{ml}$ nutrient broth in effluent sample for Paracoccus pantotrophus (TW 15), Bacillus velezensis (TW17).3\% of inoculum was added to the autoclaved nutrient broth. $200 \mathrm{ml}$ nutrient broth prepared in effluent sample without inoculums kept as control. Kept in $37^{\circ} \mathrm{C}$ for incubation and assay for the determination of $\mathrm{Cr}, \mathrm{Cd}$, and Tannic acid was carried out for 7 days.

\section{Determination of Tannin in bacterial co- cultures}

$0.1 \mathrm{ml}$ of the test sample was taken in a test tube. $7.5 \mathrm{ml}$ of distilled water is added to each of the tubes. Added $0.5 \mathrm{ml}$ of Folin phenol reagent to all the tubes. Then, $1 \mathrm{ml}$ of $35 \%$ of sodium carbonate was added to the tubes. After adjusting the volume of each tube to $10 \mathrm{ml}$ with distilled water, it was shaken well and kept for incubation for 30 minutes at room temperature. Tannic acid was used as standard solution. Based on these different standards was prepared. The absorbance was measured at $725 \mathrm{~nm}$ in a UV- Spectrophotometer. The results of the tannins are expressed in terms of tannic acid in $\mathrm{mg} / \mathrm{ml}$ of extract. Distilled water was used as blanks. (Uddin et al, 2014).

\section{Determination of chromium in bacterial co-cultures}

$5 \mathrm{ml}$ of the test sample was taken in a clean test tube. Added $1 \mathrm{ml}$ of Diphenyl carbazide (DPC) reagent to all the tubes. Then, $1 \mathrm{ml}$ of $0.2 \mathrm{~N}$ Sulphuric acid was added to the tubes. After adjusting the volume of each tube to $7 \mathrm{ml}$ with distilled water, it was shaken well and kept for incubation for 30 minutes in room temperature. Chromium was used as standard solution which was supplemented by potassium chromate. Based on these different standards were prepared. The absorbance was measured at $540 \mathrm{~nm}$ in a UV- Spectrophotometer. The results of the chromium are expressed in terms of 
chromium present in $\mathrm{mg} / \mathrm{ml}$ of extract. Distilled water was used as blanks. (Kefa et al, 2016)

\section{Determination of cadmium in bacterial co-cultures}

$1 \mathrm{ml}$ of the test sample was taken in a clean test tube. Then, $1 \mathrm{ml}$ of $0.2 \mathrm{~N}$ Sulphuric acid was added to the tubes. Added appropriate amount of alizarin red solution in the dilution of 1:5 of cadmium and alizarin solution. After adjusting the volume of each tube to $2 \mathrm{ml}$ with distilled water, it was shaken well. Cadmium sulfate was used as standard solution. Based on these different standards were prepared. The absorbance was measured at $422 \mathrm{~nm}$ in a UV- Spectrophotometer. The results of the cadmium are expressed in terms of cadmium present in $\mu \mathrm{g} / \mathrm{ml}$ of extract. Distilled water was used as blanks. (Ullah et al, 2010).

\section{RESULTS AND DISCUSSION}

\section{Inoculation of TW15, TW17 and TW15+17}
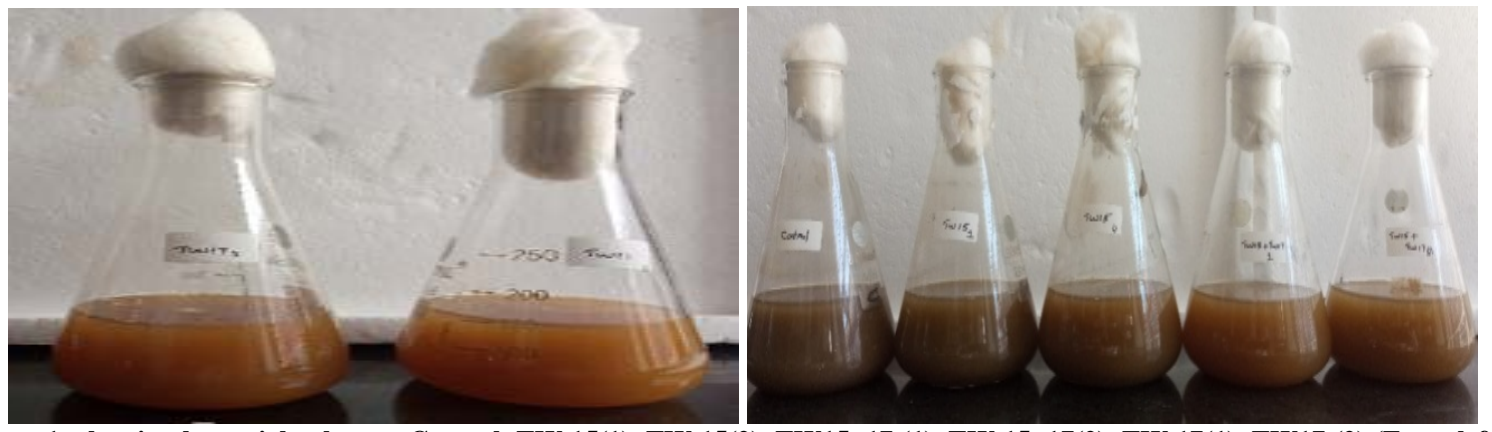

Figure 1: showing bacterial cultures: Control, TW 15(1), TW 15(2), TW15+17 (1), TW 15+17(2), TW 17(1), TW17 (2) (From left to right)

\section{Figure 2: Estimation of Tannic acid}

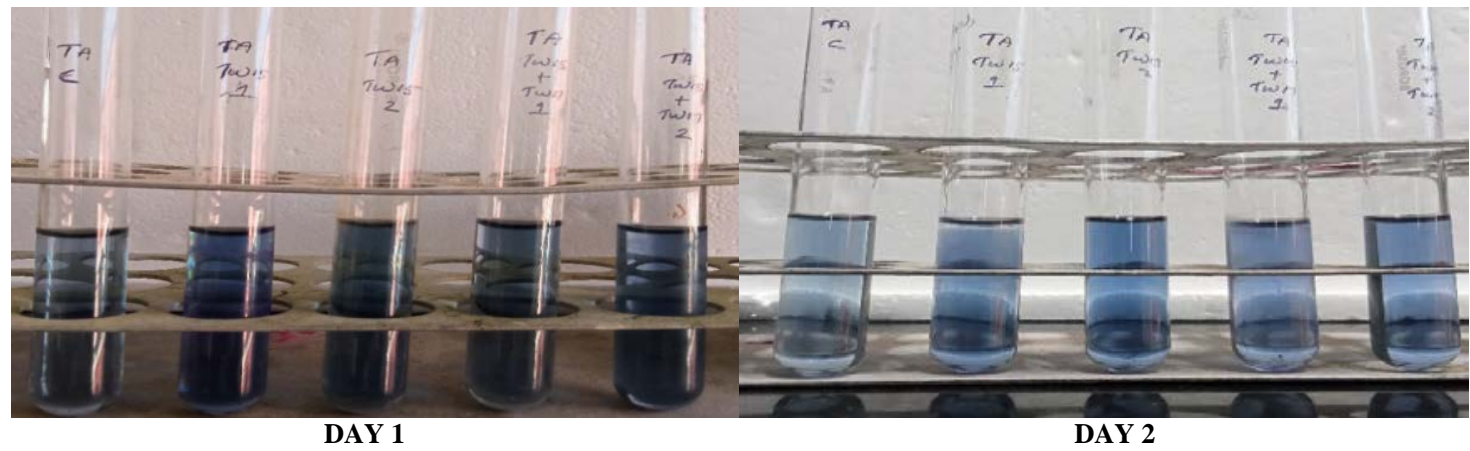


Roselin K. et.al. Biodegradation of tannic acid, chromium and cadmium present in leather industrial effluents using microorganisms isolated from leather industrial sludge.

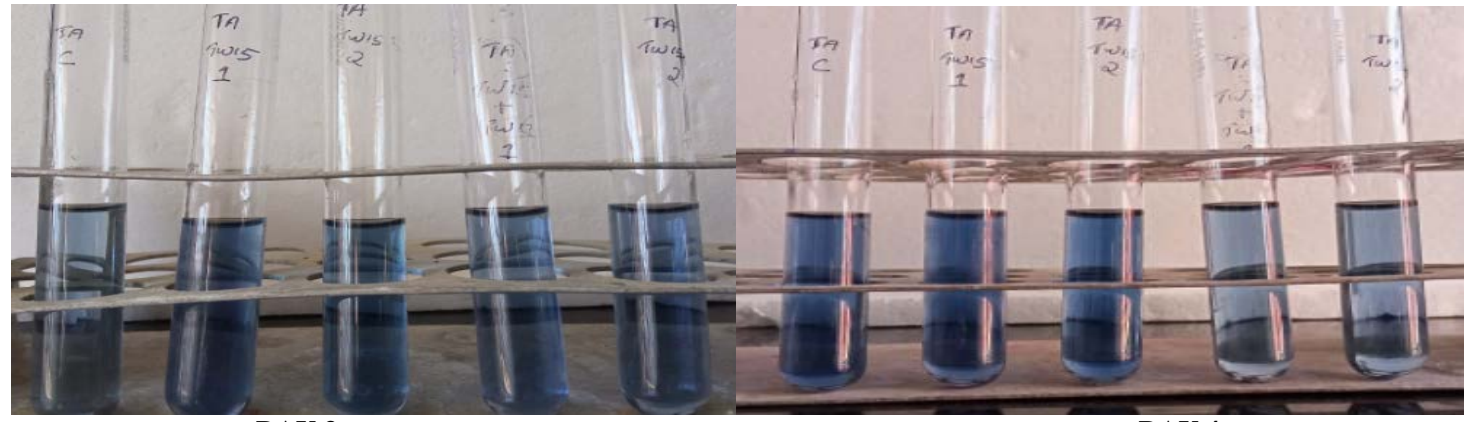

DAY 3

DAY 4

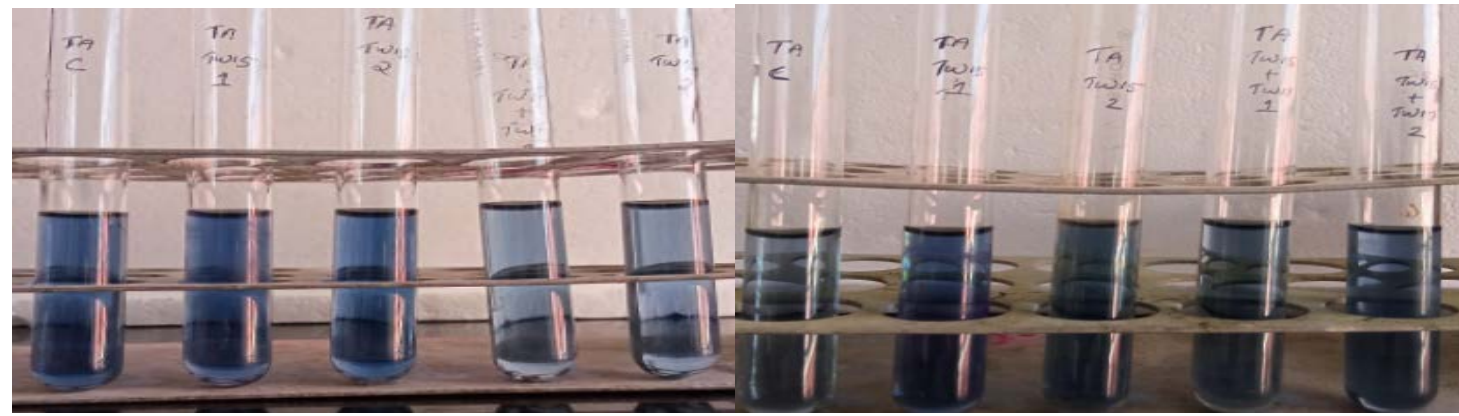

DAY 5

DAY 6

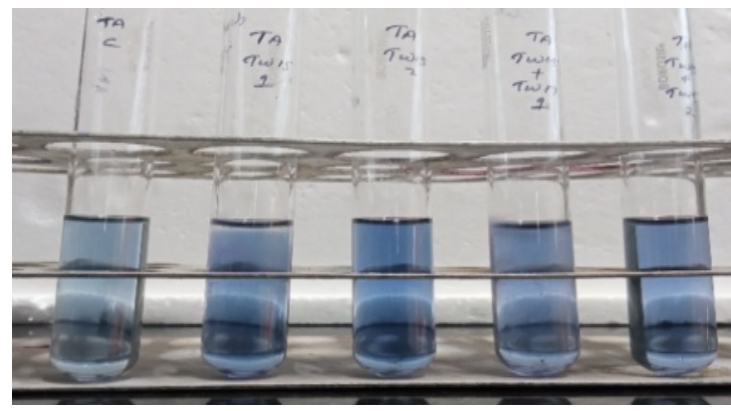

DAY 7

Figure 2: Day1-Day7: Showed assay of Tannic acid for Control, Paracoccus Pantotrophus (TW15 (1)) and Bacillus velezensis (TW17 (2)), Paracoccus pantotrophus and Bacillus velezensis( TW15+17 (1)).

Table 1: Table showing the absorbance for Tannic acid of different bacterial cultures at $725 \mathbf{~ n m}$

\begin{tabular}{|l|l|l|l|l|}
\hline \multirow{2}{*}{ DAYS } & \multicolumn{4}{|l|}{ Tannic acid (Abs at 725 nm) } \\
\cline { 2 - 5 } & C & TW 17 & TW 15 & TW 15+TW 17 \\
\hline DAY 1 & 1.264 & 0.847 & 1.413 & 0.845 \\
\hline DAY 2 & 1.254 & 0.621 & 1.367 & 0.670 \\
\hline DAY 3 & 1.210 & 0.441 & 1.279 & 0.544 \\
\hline DAY 4 & 1.223 & 0.415 & 1.197 & 0.473 \\
\hline DAY 5 & 1.211 & 0.403 & 1.020 & 0.444 \\
\hline DAY 6 & 1.189 & 0.395 & 0.994 & 0.376 \\
\hline DAY 7 & 1.109 & 0.383 & 0.915 & 0.274 \\
\hline
\end{tabular}

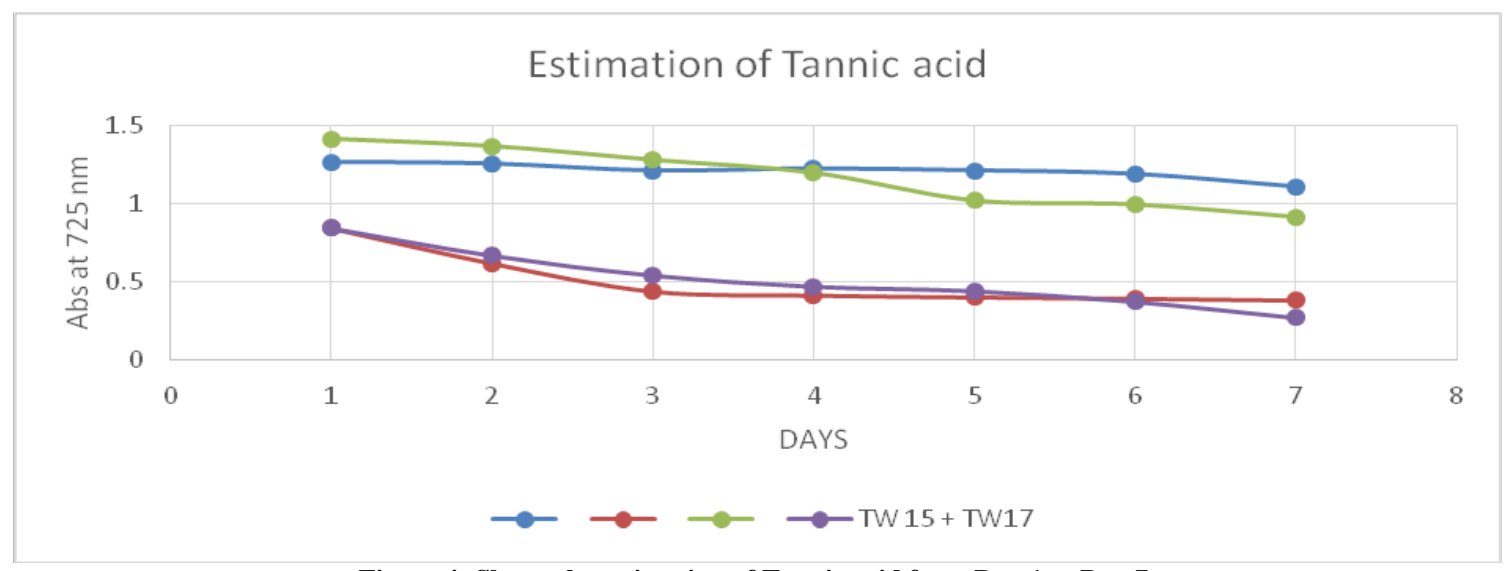

Figure 4: Shows the estimation of Tannic acid from Day 1 to Day 7. 
Roselin K. et.al. Biodegradation of tannic acid, chromium and cadmium present in leather industrial effluents using microorganisms isolated from leather industrial sludge.

\section{Degradation of Cadmium}

From the table 2 and figure 5 , it is noticeable that both Paracoccus pantotrophus (TW 15 and Bacillus velezensis (TW 17) bacteria have the ability to degrade $\mathrm{Cd}$. They show maximum degradation of $\mathrm{Cd}$ on $7^{\text {th }}$ day and the absorbance was found to be 2.013 for Bacillus velezensis (TW 17) and 1.709 for Paracoccus pantotrophus (TW 15).
Degradation increases with time. Bacillus velezensis (TW 17) shows minimal degradation from $4^{\text {th }}$ day to $7^{\text {th }}$ day. Paracoccus pantotrophus (TW 15) is more efficient in the degradation of $\mathrm{Cd}$ than Bacillus velezensis (TW 17). When it cultured together it shows maximum degradation of $\mathrm{Cd}$ and the degradation is double than when it cultured individually.

\section{Estimation of cd}

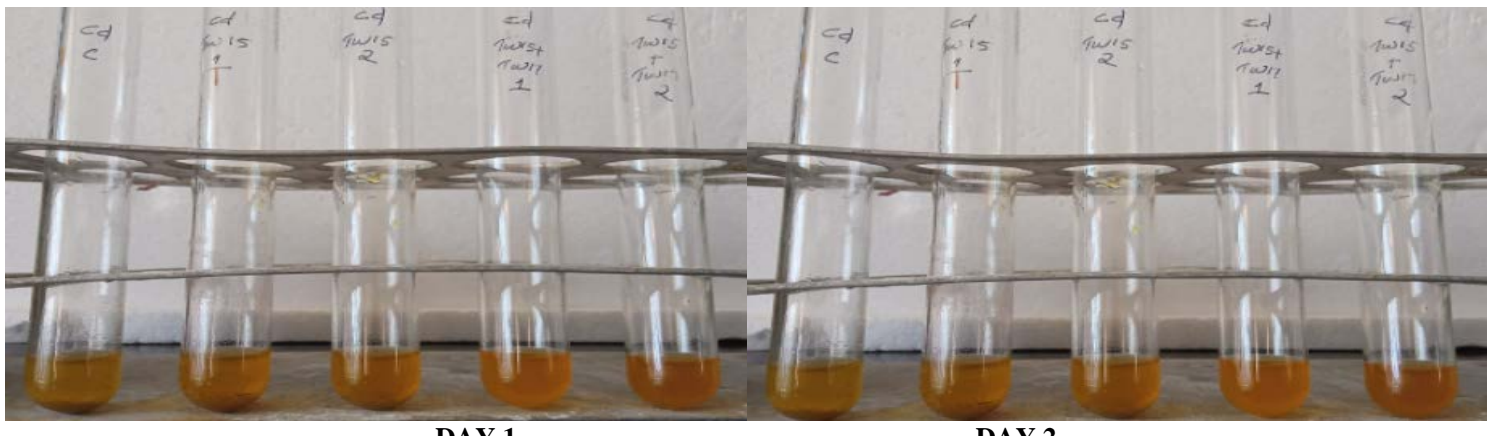

DAY 1

DAY 2
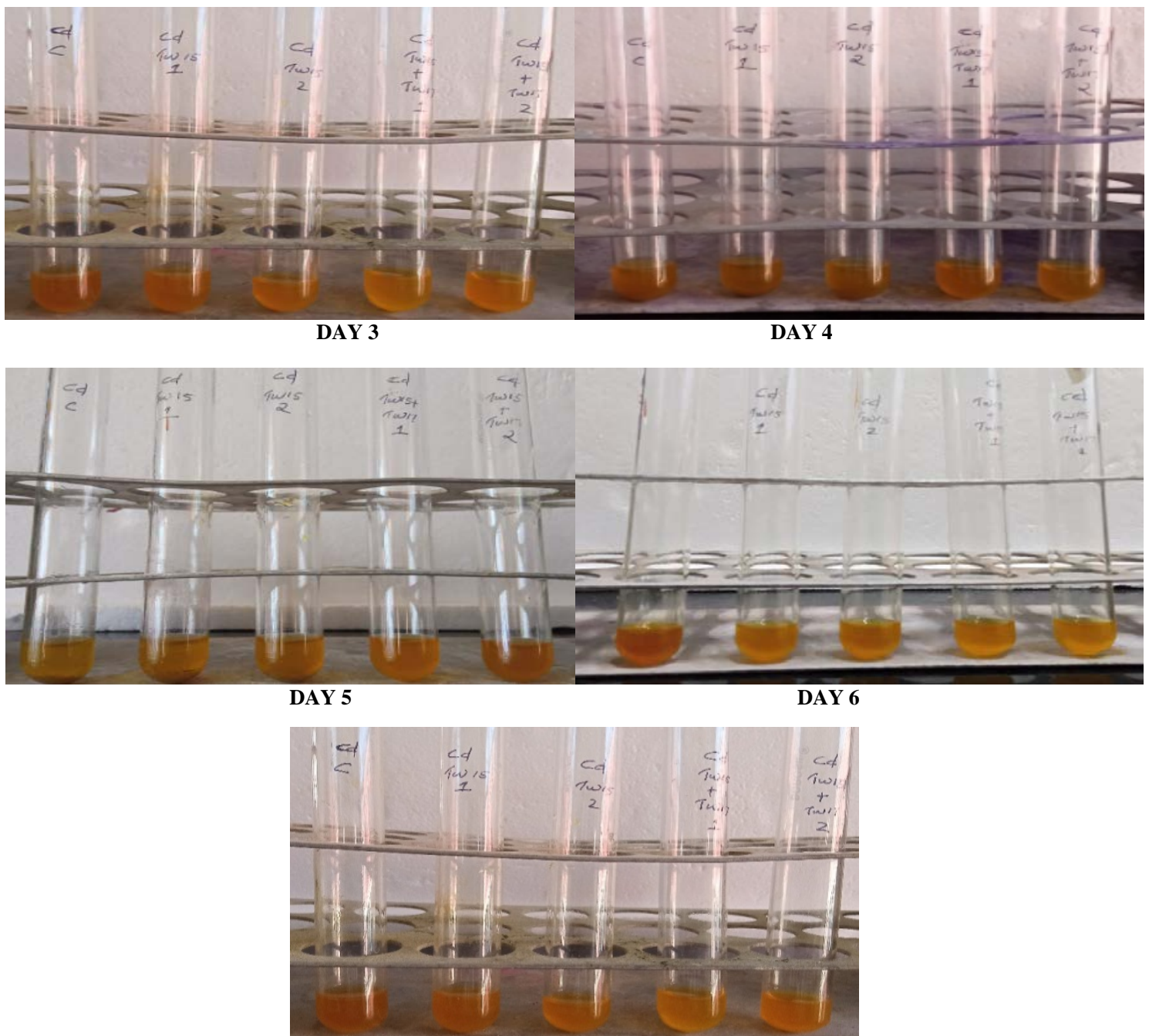

DAY 7 
Roselin K. et.al. Biodegradation of tannic acid, chromium and cadmium present in leather industrial effluents using microorganisms isolated from leather industrial sludge.

Figure 4: Day1-Day7: Shows assay of Cd for Control, TW15 (1), TW15 (2), TW15+17 (1) and TW15+17 (2) respectively. Table 2: showing the absorbance for Cd of different bacterial cultures at 422

\begin{tabular}{|l|l|l|l|l|}
\hline \multirow{2}{*}{ DAYS } & \multicolumn{4}{|l|}{ Cd(Abs at 422 nm) } \\
\cline { 2 - 5 } & C & TW 17 & TW 15 & TW 15 +TW 17 \\
\hline DAY 1 & 2.310 & 2.888 & 2.353 & 2.271 \\
\hline DAY 2 & 2.305 & 2.87 & 2.185 & 1.430 \\
\hline DAY 3 & 2.201 & 2.517 & 2.045 & 1.25 \\
\hline DAY 4 & 2.210 & 2.248 & 1.890 & 1.05 \\
\hline DAY 5 & 2.209 & 2.212 & 1.823 & 0.901 \\
\hline DAY 6 & 2.189 & 2.158 & 1.781 & 0.724 \\
\hline DAY 7 & 2.178 & 2.013 & 1.709 & 0.659 \\
\hline
\end{tabular}

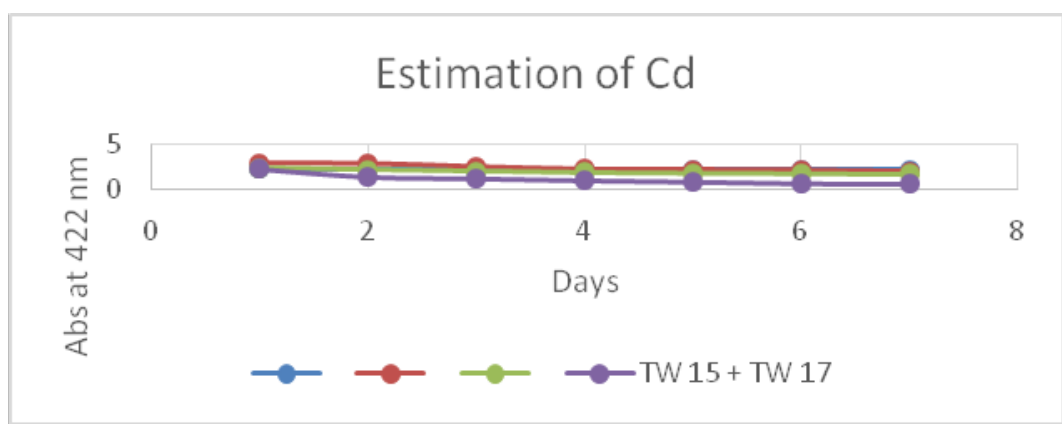

Figure 5: Shows the estimation of Cd from Day 1 to Day 7.

\section{Estimation of $\mathbf{C r}$}

Table 3 and Figure 5 indicates that both Paracoccus pantotrophus (TW 15) and Bacillus velezensis (TW 17) bacteria has the ability to degrade Cr. Bacillus velezensis (TW 17) has more ability to degrade Cr than TW 15 and mixed cultures of Paracoccus pantotrophus (TW 15) and TW 17. They showed maximum degradation of $\mathrm{Cr}$ on $7^{\text {th }}$ day. Absorbance was found to be 2.096 for Paracoccus pantotrophus (TW 15) and 0.560 for Bacillus velezensis (TW 17). The degradation increases with time.

\section{Estimation of $\mathrm{Cr}$}

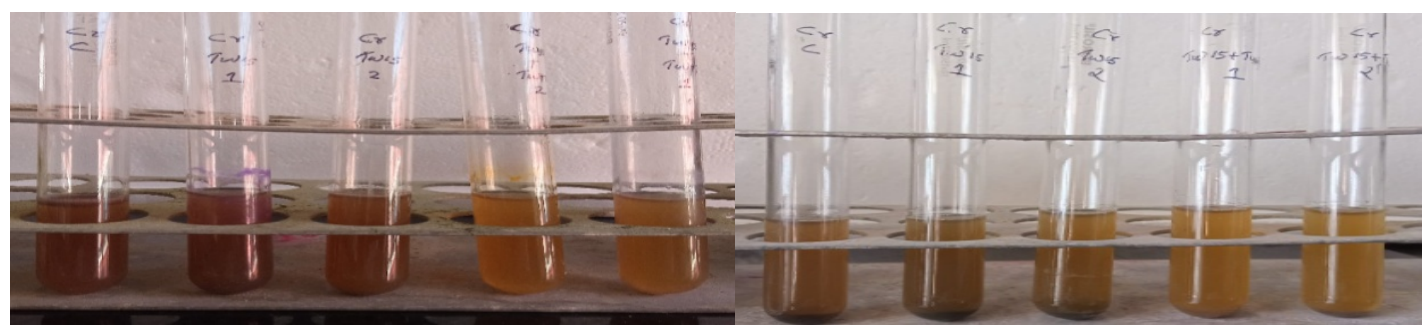

DAY 1

DAY 2

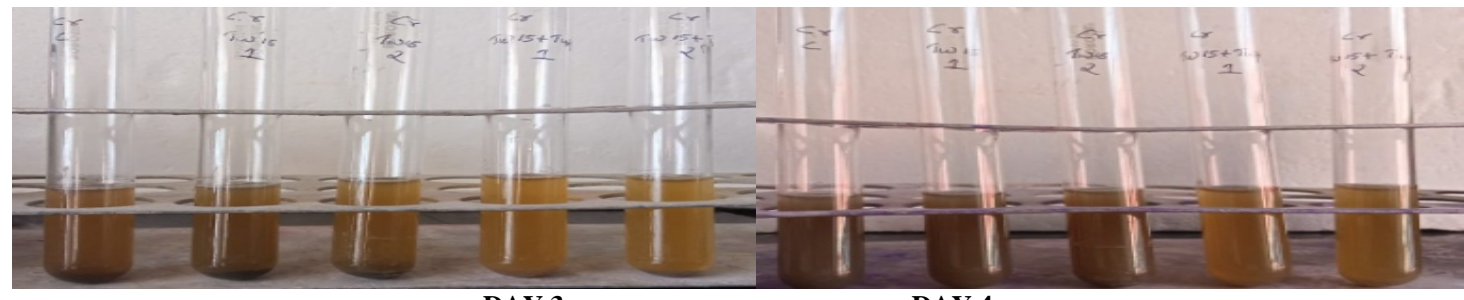

DAY 3

DAY 4

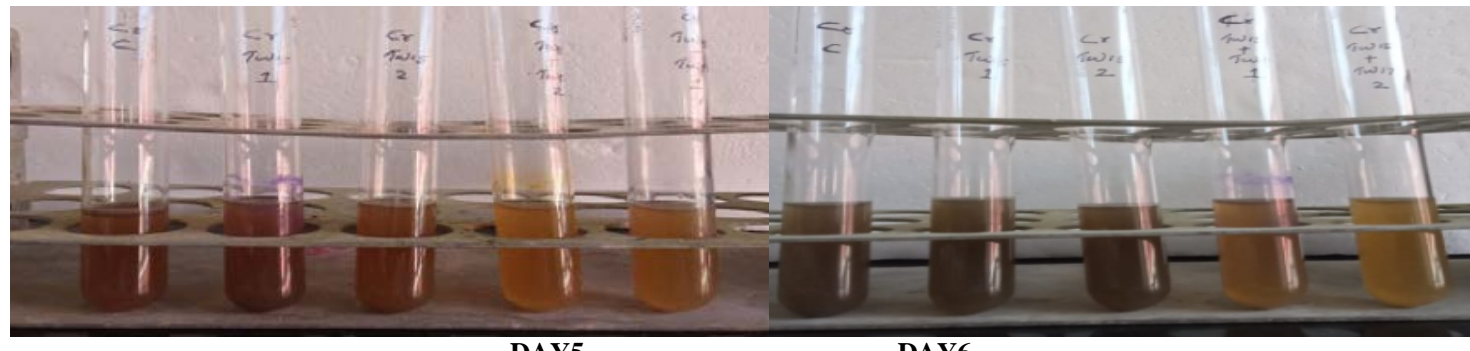

DAY5

DAY6 
Roselin K. et.al. Biodegradation of tannic acid, chromium and cadmium present in leather industrial effluents using microorganisms isolated from leather industrial sludge.

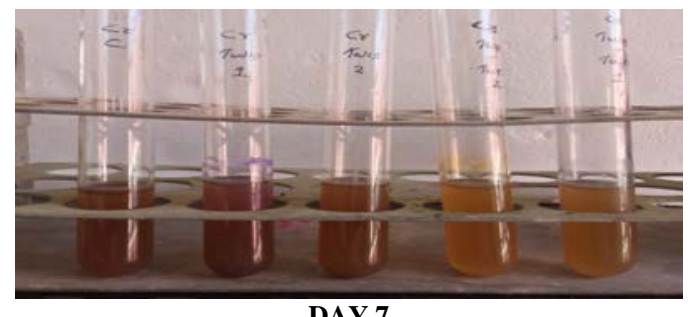

Figure 6: Day1-Day7: Shows assay of Cd for Control, TW15 (1), TW15 (2), TW15+17 (1) and TW15+17 (2) respectively.

Table 3: showing the absorbance for $\mathrm{Cr}$ of different bacterial cultures at $540 \mathbf{~ n m}$

\begin{tabular}{|l|l|l|l|l|}
\hline \multirow{2}{*}{ DAYS } & \multicolumn{4}{|l|}{ Cr (Abs at $540 \mathbf{~ n m ) ~}$} \\
\cline { 2 - 5 } & C & TW 15 & TW 17 & TW 15+TW17 \\
\hline DAY 1 & 2.412 & 2.457 & 0.886 & 1.786 \\
\hline DAY 2 & 2.501 & 2.448 & 0.716 & 1.652 \\
\hline DAY 3 & 2.486 & 2.407 & 0.705 & 1.595 \\
\hline DAY 4 & 2.401 & 2.392 & 0.675 & 1.445 \\
\hline DAY 5 & 2.400 & 2.359 & 0.632 & 1.412 \\
\hline DAY 6 & 2.433 & 2.214 & 0.584 & 1.369 \\
\hline DAY 7 & 2.398 & 2.096 & 0.560 & 1.294 \\
\hline
\end{tabular}

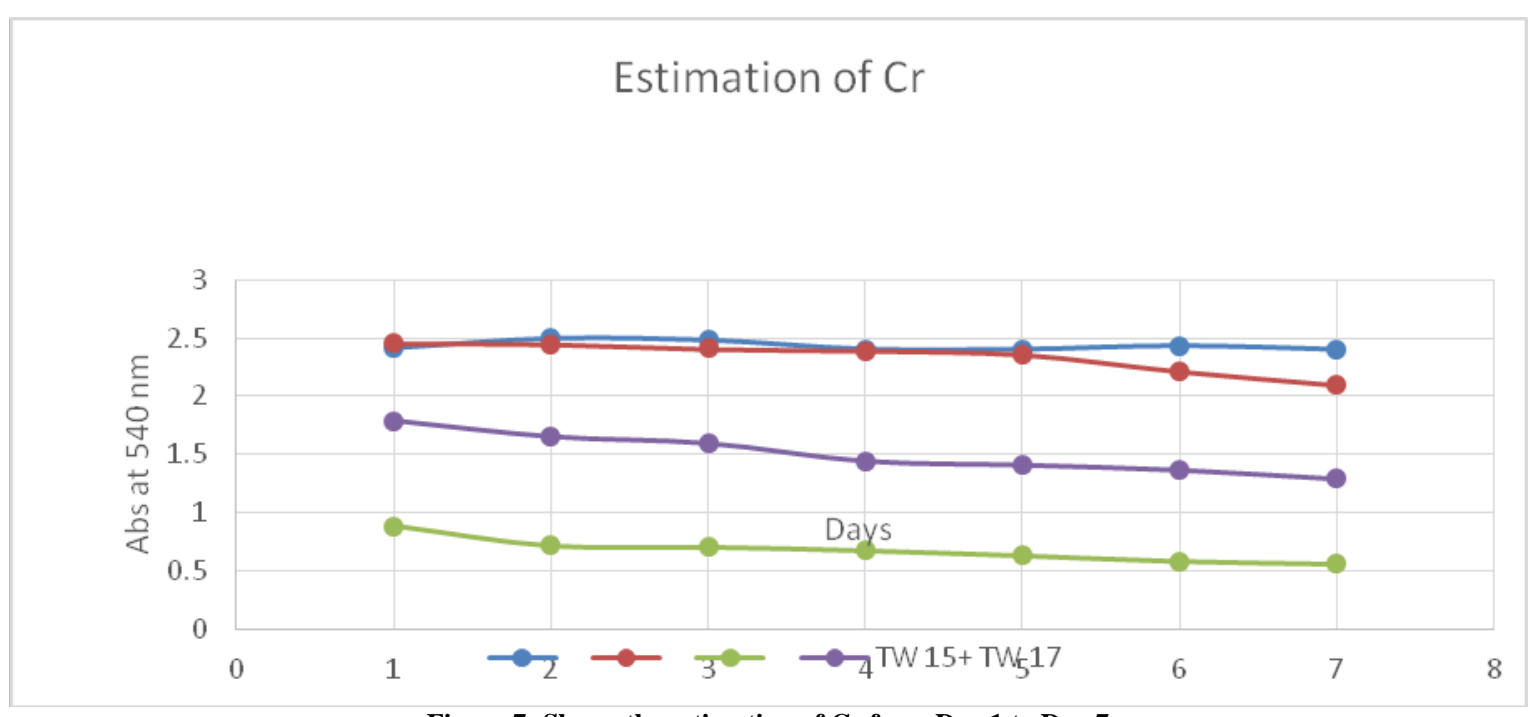

Figure 7: Shows the estimation of Cr from Day 1 to Day 7

Recent research has found that even low levels of chromium, lead, mercury, cadmium, aluminium and arsenic can cause a wide variety of health problems (Arief et al. 2008; Katiyar et al. 2008), and the long time exposure may lead to immunemodulation (Katiyar 2011; Tabesh et al. 2011). It is necessary to develop some awareness among the people for avoiding water contaminated with heavy metals. So, the treatment of the effluents before discharging them in the environment is mandatory.

\section{CONCLUSION}

A total number of 15 Bacteria isolates were isolated from tannery sludge samples Paracoccus pantotrophus and
Bacillus velezensis were found to be the most efficient isolates. Both Paracoccus pantotrophus and Bacillus velezensis bacteria have the ability to degrade Tannic acid. Showed maximum degradation of tannic acid on $7^{\text {th }}$ day and absorbance was found to be 0.915. Bacillus velezensis showed maximum degradation on $7^{\text {th }}$ day and the absorbance was found to be 0.383 . Bacillus velezensis showed minimal degradation from $3^{\text {rd }}$ day to $7^{\text {th }}$ day and it is more efficient in the degradation of tannic acid than Paracoccus pantotrophus. When cultured together, it showed maximum degradation of Tannic acid and the absorbance was found to be 0.274 . It is also noticeable that both Paracoccus pantotrophus and Bacillus velezensis 
Roselin K. et.al. Biodegradation of tannic acid, chromium and cadmium present in leather industrial effluents using microorganisms isolated from leather industrial sludge.

bacteria have the ability to degrade Cd. They showed maximum degradation of $\mathrm{Cd}$ on $7^{\text {th }}$ day and the absorbance was found to be 2.013 for Bacillus velezensis and 1.709 for Paracoccus pantotrophus. Degradation increases with time. Bacillus velezensis showed minimal degradation from $4^{\text {th }}$ day to $7^{\text {th }}$ day. Paracoccus pantotrophus is more efficient in the degradation of $\mathrm{Cd}$ than Bacillus velezensis. When it cultured together it shows maximum degradation of $\mathrm{Cd}$ and the degradation is double than when it is cultured individually. Paracoccus pantotrophus and Bacillus velezensis (TW 17) bacteria have the ability has more ability to degrade $\mathrm{Cr}$ than Paracoccus pantotrophus and mixed cultures of Paracoccus pantotrophus and Bacillus velezensis. They showed maximum degradation of $\mathrm{Cr}$ on $7^{\text {th }}$ day. Absorbance was found to be 2.096 for Paracoccus pantotrophus and 0.560 for Bacillus velezensis. The degradation increases with time. The present study indicates biodegradation potential of Paracoccus pantotrophus and Bacillus velezensis against $\mathrm{Cr}, \mathrm{Cd}$ and tannic acid degradation in tannery effluent.

\section{Acknowledgement: None}

\section{Conflict of Interest: None}

\section{Source of Funding: None}

\section{Ethical Approval: Approved}

\section{REFERENCES}

1. Ayangbenro and O. Babalola, "A new strategy for heavy metal polluted environments: a review of microbial biosorbents," International Journal of Environmental Research and Public Health, vol. 14, no. 1, p. 94, 2017.

2. Chamka M, Record E, Garcia JL, Asther M, Labat M. Isolation from a shea cake digester of a tannin-tolerant Escherichia coli strain decarboxylating p-hydroxybenzoic and vanillic acids. CurrMicrobiol 2002; 44: 341- 349.

3. Chandra T, Krishnamurty V, Madhava Krishna W, Nayudamma Y (1973)
Microbial degradation of tannins and related compounds. Leather science 20: 269-273.

4. Dai J, Mumper RJ. Plant phenolics: extraction, analysis and their antioxidant and anticancer properties. Molecules. 2010; 15: 7313- 7352.

5. Deschamps AM, Mahoudeau G, Conti M, Lebeault JM (1980) J Ferment Technol 58: 93-97.

6. Frutos P, Hervás G, Giráldez FJ, Mantecón AR. (Review). Tannins and ruminant nutrition. J Agri Res 2004; 8: 191- 202.

7. Garg SK, Tripathi M, Srinath T. Reviews of environmental contamination and toxicology. Berlin: $\quad$ Springer; 2012. Strategies for chromium bioremediation of tannery effluent; pp. 75-140.

8. He and J. P. Chen, "A comprehensive review on biosorption of heavy metals by algal biomass: materials, performances, chemistry, and modeling simulation tools," Bioresource Technology, vol. 160, pp. 67-78, 2014.

9. Langard, S. (1980): A survey of respiratory symptoms and lung function in ferrochromium and ferrosilicon workers. Internat. Arch. of Occup. And Environ. Heal. 46:1-9.

10. Lewis JA, Starkey RL (1968) the process of formation of soil organic matter or humus is primarily a...seldom, if ever, are added tosoils except by scientists for experimental purposes. Soil Sci 106: 241-247.

11. Malarkodi, M.; Krishnasamy, R.; Kumaraperumal, R.; Chitdeshwari, T. Characterization of heavy metal contaminated soils of Coimbatore district in Tamil Nadu. Journal of Agronomy, v. 6, No. 1, p. 147-151, 2007. https://doi.org/10.3923/ja.2007.147.151

12. Mark I, Stanley D (1981) Bacterial degradation of 3, 4, 5-trimethoxycinnamic acid with production of methanol. J Bacteriol 147: 471-475.

13. Megharaj, M., S. Avudainayagam, and R. Naidu, Current microbiology, 2003. 47(1): p. 0051-0054.

14. Mueller-Harvey I. Analysis of hydrolysable tannins. Anim Feed SciTechnol 2001; 91: 320.

15. Piñón-Castillo, H., et al., Journal of applied microbiology, 2010. 109(6): p. 2173-2182.

16. Raskin, I., Ensley, B.D., (2000). Phytoremediation of toxic metals. John Wiley \& Sons, New York 
Roselin K. et.al. Biodegradation of tannic acid, chromium and cadmium present in leather industrial effluents using microorganisms isolated from leather industrial sludge.

17. Singanan M, Abebaw A, Singanan V. Studies on the removal of hexavalent chromium from industrial wastewater by using biomaterials. EJEAF Che. 2007; 6(11):2557-2564.

18. Scalbert A. Antimicrobial properties of tannins. Phytochem 1991; 30: 3875- 3883.

19. Sivasamy SN (1982) Effect of tan liquor and tannins on microorganisms, Doctoral Thesis, Universityof Madras, Chennai, p: 229.

20. Sultan S, Hasnain S. Reduction of toxic hexavalent chromium by Ochrobactrum intermedium strain SDCr-5 stimulated by heavy metals. Bioresour Technol. 2007;
98(2):340-344.

doi: 10.1016/j.biortech.2005.12.02.

21. Viswarajan S (1988) Effect of tannery effluent on the physiology of chosen Thermoconformers. Doctoral Thesis, Madras University, Chennai, p: 165.

How to cite this article: Roselin K., J. Caroline Rose. Biodegradation of tannic acid, chromium and cadmium present in leather industrial effluents using microorganisms isolated from leather industrial sludge. International Journal of Research and Review. 2021; 8(12): 503-512. DOI: https://doi.org/10.52403/ijrr.20211262 